\title{
Changing society's DNA codes: Democracy and the global movement for community progress measures
}

\author{
Mike Salvaris, Geoff Woolcock
}

\begin{abstract}
This paper examines some critical issues and opportunities for democracy and public policy posed by the growth of the global progress measurement movement. From the democratic perspective, these include: citizen progress measurement as a form of democratic re-engagement; the re-examination of democracy and the development of new indicators to define and measure a 'healthy' democracy; and the demonstration of clear linkages between healthy regimes, and broader individual and societal wellbeing. In public policy, the global movement challenges two long dominant assumptions: the primacy of continuous economic growth as the key driver of wellbeing; and the 'inevitability of progress'. In their place, it offers a more holistic, integrated and nuanced model that recognises the interdependence of economic, social, cultural, environmental and democratic dimensions for genuine wellbeing, progress and sustainability. The paper reviews work in Australia over the past decade at both local community and national levels as examples of these trends, including the development of citizen-engaged community planning and neighbourhood renewal schemes in which progress and wellbeing indicators play a central role; the development of state-wide local progress measurement frameworks as part of a commitment to devolved planning and stronger local democracy; and the evolution of national progress measurement systems. The paper concludes with a proposal for a broad community engaged National Development Index (NDI) for Australia.
\end{abstract}

Keywords: measuring progress, healthy democracies, community wellbeing 


\section{Introduction}

Citizen based progress measurement is a global movement, which has the potential to create a new paradigm for democracy and good governance. The benefits may be substantial: new and more dynamic forms of democratic engagement; new ways to define and measure a 'healthy' democracy; the demonstration of clearer linkages between strong democratic and human rights regimes, and broader individual and societal wellbeing; and perhaps most important, a re-examination of the nature of progress and democracy in the 21st century democracy.

It is worth reflecting briefly on why the measurement of progress is ultimately a democratic rather than a technocratic issue, a question often overlooked in contemporary discussions about progress measurement. We contend that democracy and the measurement of social progress are connected in fundamental ways, and around at least five specific issues. First, defining progress ought to be the proper responsibility of democratic citizens. This is because the way we define and measure progress officially and in public policy has a major impact on the wellbeing of citizens and the development and priorities of nations and communities; and so in a democracy these collective decisions should be made democratically. Secondly, democracy, human rights and good governance are themselves an integral part of the idea and the meaning of progress, and they therefore should be measured in their own right. Social progress necessarily implies improving democracy and human rights.

Third, a healthy democracy tends to produce progress and wellbeing in other areas: that is, the quality and effectiveness of democracy and human rights in a society is one of the key drivers of the wellbeing of its citizens. Fourth, progress and wellbeing indicators are a powerful tool for good democratic governance, especially in improving planning, evaluation, transparency and accountability.

Finally, we know that engaging citizens in developing the goals and measures of progress, whether for a community or a nation, is itself an important way to strengthen democratic process. It is one of the answers to the pervasive modern problem of democratic disengagement and alienation; and may even prove to be a new form of democracy in its own right.

\section{Defining Progress is a Democratic Task}

Over a decade ago, the UN Development Program (UNDP 1996) called for an end to what it described as "the mismeasurement of progress by economic growth alone". It recognised that a new and 'more legitimate' paradigm must be "people centred, equitably distributed and environmentally and socially sustainable - human advance is conditioned by our conception of progress". The term 'more legitimate' is crucial: how social progress is defined and measured is an issue of fundamental importance for democracy - and for human rights and good governance. 
Defining progress is a political act. Historically, from Plato to Marx via Hobbes, control over measuring and definitions (good and bad, true and false, just or unjust) has been seen as a key tool of political power. And this is especially true of the act of defining and measuring progress. 'Progress' is a politically powerful idea, but one that is complex and contestable. It is politically powerful because it conveys a sense of destiny, a force that cannot be stopped; and those who can define it wield power. Yet it has legitimately different meanings, and different impacts. What is progress? Progress for whom? And who should decide?

Since Aristotle's notion of the good society, people have had different ideas of progress. Both within and between nations, what is progress for some is regression for others. In its broadest sense, the history of the development of community progress and wellbeing indicators encompasses the full range of debates about the nature of the 'good life' and the 'good society'. At the same time, from the 1086 Domesday book onwards, the collection and analysis of data about social conditions and trends has also reflected the tensions between 'top down' and 'bottom up' approaches - between the desire of rulers and policy makers to monitor and manage social outcomes and the desire of communities and citizens to prioritise and address local goals and concerns. Decisions about the choice of indicators and about the way data is collected, analysed and interpreted are all, in the end, political decisions.

The political and policy implications of choices about progress indicators are particularly clear in the emergence of Gross Domestic Product (GDP) as an all encompassing proxy measure of societal progress in the period following World War II (Cobb \& Rixford 1998). The narrowness of the GDP index increasingly came under fire from a number of quarters. Feminists pointed to the ways in which much of the unpaid work carried out by women was simply invisible in GDP accounting (Waring 1988). Development agencies such as the United Nations Development Program noted the need to include health, education, housing and income inequality outcomes and trends (UNDP 1996). The environment movement became a strong advocate for the inclusion of environmental trends as well as highlighting the ways in which economic growth often involves environmental costs as well as benefits.

By the 1970s governments, statistical agencies and academic researchers were therefore developing a more integrated range of economic, social, environmental and cultural progress measures (Estes 1984; Vinson \& Homel 1976). The rise of neo-liberal and managerialist policy settings in the $1980 \mathrm{~s}$ slowed this initial work on community wellbeing indicators and brought a renewed focus on economic performance and efficiency as defined by the more readily quantifiable measures of financial costs and benefits. By the late 1990s, however, the backlash against the more extreme forms of economic rationalism, and increasing support for 'triple bottom line' policy making and reporting, had again begun to create a favourable climate for a more holistic approach to community indicators. 
In Australia, there has been a growing movement toward using community wellbeing indicators to support more informed and engaged approaches to community planning and health promotion and social inclusion (Salvaris \& Wiseman 2004). There is increasing interest in exploring approaches to understanding and measuring the progress of societies which extend beyond GDP to more inclusive, holistic and multi-domain frameworks (ABS 2006). Wellbeing indicators and sustainability frameworks seek to complement understandings of economic wellbeing with social, environmental and cultural understandings (Gahin and Paterson 2001).

The community indicator movement has expanded internationally in a context of a general upsurge of interest in community engagement and place based responses to complex social issues (Dluhy \& Swartz 2006). It represents a "rush back to the idea of community" by governments and policy makers (Adams and Hess 2001) and is matched by growing evidence that citizen engagement contributes to better policy outcomes and a stronger sense of inclusion, participation and community (Callahan 2007). The literature reflects:

- An upsurge of interest in social capital and community building (Woolcock \& Manderson 2009; Putnam 2000);

- The reawakening of interest in citizenship, local democracy, governance and social justice (Smyth, Rydell et al. 2005);

- The influence of systems theory, complexity and the striving for joined up government, innovation and new efficiencies in public administration (Chapman 2004); and

- The increasing recognition that the implementation of effective and sustainable strategies for the promotion of health and well-being requires ongoing development of indicators (Wiseman et al. 2007).

\section{Measurement as a Democratic Issue}

As progressive as these historical developments have been in expanding notions of progress, it is important to remember that the measurement of progress has not been seen as a democratic issue until recently, and in many places it still is not, being considered rather as the prerogative of governments or experts. And likewise, the idea of measuring democracy and human rights is neither well developed nor widely accepted.

Some of the key democratic questions in measuring progress stem from the nature and use of statistics themselves. In modern societies, statistics are a powerful tool to manage people and control understanding: and so progress indicators raise a crucial democratic issue about information and influence. Political and corporate managers increasingly insist upon summarised information and evidence based policy, and they inevitably have the clout and technology to ensure they get the best. But ordinary citizens can only hope to have limited understanding of all the information they need to make sense of their world and make the best decisions about their lives, their families, their work and their government. 
In these conditions, indicators and statistics are a powerful tool of influence on policy and decision making as well as on public reporting and debate, to the point where they may become a kind of societal DNA code, as Henderson (1991) highlighted, or a version of holy grail, that many worship but few understand - such as GDP. Thus indicators can become instruments for consolidating inequality or for democratising information. But of course statistical indicators are not mystical: they are the creation of people, people with problems and people with particular values and prejudices, and underlying them there is always a human story, as Raymond Bauer (1966) powerfully demonstrated. Measurement is thus a human act; it is rarely totally scientific or impartial. It embodies the values of the measurer: we measure what we think important and ignore what we do not.

The significance of community indicators and their democratic promise lies also in the fact that 'indicators' are meant to be more than statistics: their function is to tell us about something that is important, something that is collectively valued. In a democratic society, it stands to reason that decisions about collective values and priorities should be submitted to a democratic process. Decisions about what is important, what is valued and what constitutes 'progress'- that is, where we should be heading as a nation or community - are ultimately democratic decisions of the citizens as a whole.

But to go one step further, measuring social progress is a more complex task than simply identifying collective values or relevant data. Logically, to construct a coherent set of progress indicators, one cannot simply bundle together a collection of statistics or values. Instead, one must have some overall framework, some theory of what is progress or a good society, as Kenneth Land (1974) identified some time ago: "To develop social indicators that can evaluate the health of society, we are faced with the necessity of spelling out some more or less explicit working model of society."

\section{Table 1: Most important qualities for Australia's progress}

\begin{tabular}{c|lc}
\hline Rank & Quality & Average \\
\hline 1 & Honesty and ethics in public life & 9.42 \\
\hline 2 & Security and stability & 9.33 \\
\hline 3 & Environmental responsibility & 9.25 \\
\hline 4 & Democracy, open, accountable government & 9.17 \\
\hline 5 & Efficiency in government, management etc & 9.10 \\
\hline 6 & Economic strength & 9.04 \\
\hline 7 & Happiness and health & 9.02 \\
\hline 8 & Fairness & 8.90 \\
\hline 9 & Education and creativity & 8.74 \\
\hline 10 & Inclusiveness and community & 8.65 \\
\hline 11 & International responsibility & 8.65 \\
\hline 12 & High living standards & 8.59 \\
\hline 13 & Diversity and tolerance & 8.50 \\
\hline 14 & High technology & 8.43 \\
\hline 15 & Political power & 7.69 \\
\hline 16 & Competitiveness & 7.68 \\
\hline
\end{tabular}


In Canada, a process of extensive community debate over several years led to the development of the Canadian Index of Wellbeing, officially launched in June 2009, and the central question asked was: 'What kind of society do we want Canada to be?' In Australia, a similar question was posed as part of the development of the Australian Bureau of Statistics (ABS) national project Measures of Australia's Progress (MAP), where people were asked in 2001 what they thought were the most important goals for Australia's development.

\section{Democracy is Part of the Meaning of Progress}

Some logical reasons have been suggested above as to why the process of defining and measuring progress should be conducted openly and democratically. Another way of viewing this relationship is that democracy and human rights are themselves an important component of progress; it is difficult to see how a society could be said to have made progress if human rights and democracy have declined. This suggests that we need strong indicators of the health and progress of democracy and human rights, in and of themselves.

The idea of measuring progress in democracy is very recent (Inkeles 1991). Governments have largely discouraged it because they have found it threatening. Statisticians have not been enthusiastic either: there were, and still are, conceptual difficulties in measurement; and of course, legitimate differences in the meaning and understanding of what democracy is, and therefore what should be measured (Munck 2009).

In most Western societies, democracy is a term with enormous emotional and political weight. In many established democracies today, commentators are describing a serious decline in the quality of democratic life and practice, amounting even to a democratic crisis (Dalton 2004; Sawer et al. 2009); yet at the same time, editors and politicians continue to invoke the glories of 'our model' of democracy, often on the basis of smug assumptions and over-reliance on outdated institutions rather than any rational measure of true democratic health. If our leaders genuinely believed in the importance of democracy, one might expect they would be prepared to subject it to regular review and audit; goals would be set for its continuous improvement; and there would be an eagerness to introduce innovations and best practice from elsewhere. Perhaps in the end, actual democracy is simply too radical an idea for powerful people and institutions.

Fortunately, change is starting to happen in some countries: in the past decade, national inquiries into the problem of democratic decline have been instituted in Sweden, Norway, the UK and Canada; and democratic 'audits' have been undertaken in half a dozen more.

In Australia, the nature and extent of the 'democratic deficit' has been mapped by surveys asking people which aspects of democracy they think most important, and which they perceive to be performing well or poorly. Interestingly, people nominated the honesty and integrity of politicians as one 
of the most important issues - and problems - for Australian democracy, along with low levels of public confidence in taxation, legal and political equality and media diversity.

Table 2: How do Australians rate their democracy?

\begin{tabular}{l|llc}
\hline & A & B & C \\
\hline Fair taxation & 9.0 & 3.4 & -5.6 \\
\hline Honesty in public life & 9.3 & 4.3 & -5.0 \\
\hline Trust in other people & 8.4 & 3.9 & -4.5 \\
\hline Diverse media & 7.9 & 3.7 & -4.2 \\
\hline Equal treatment before the law & 9.3 & 5.4 & -3.9 \\
\hline Confidence in public institutions & 9.0 & 5.1 & -3.9 \\
\hline Good basic services (health, education etc) for all & 9.1 & 5.5 & -3.6 \\
\hline People taking responsibility for others & 8.7 & 5.1 & -3.6 \\
\hline Reasonable equality in wealth and power & 6.8 & 3.3 & -3.5 \\
\hline Upholding and respecting the law & 8.6 & 5.5 & -3.1 \\
\hline People participating in decision-making & 8.1 & 5.1 & -3.0 \\
\hline Equal opportunities for men and women & 9.0 & 6.4 & -2.6 \\
\hline Protecting basic human rights of all citizens & 9.1 & 6.6 & -2.5 \\
\hline Freedom of speech & 8.1 & 6.3 & -1.8 \\
\hline Religious freedom & 8.2 & 7.5 & -0.7 \\
\hline Freedom to do what we like if we don't harm others & 7.4 & 7.1 & -0.3 \\
\hline Having similar values and lifestyles & 4.5 & 4.6 & +0.1 \\
\hline
\end{tabular}

Note: $A=$ How important; $B=$ How we perform; $C=$ The gap (Average rating out of 10 )

Source: Mike Salvaris, Institute for Social Research, Swinburne University of Technology. Results from study 'Citizen Benchmarks Survey' carried out in 1998-99 as part of the project 'National Citizenship Indicators' project.

Since 2002 the Democratic Audit of Australia (http://democraticaudit.org.au/), a major democracy assessment project, has been applying an internationally tested set of indicators to Australian political institutions and practices. The indicators derive from four basic principles - political equality, popular control of government, civil liberties and human rights and the quality of public deliberation. Comparative data are taken from Australia's nine jurisdictions, as well as from three comparator democracies, Canada, New Zealand and the United Kingdom, to identify strengths, weaknesses and opportunities for reform.

Some of the findings are disturbing. For example, Australia has fallen well behind in the regulation of private money in elections and in controlling the use of government or parliamentary resources for partisan benefit. Transparency and accountability have suffered from relatively weak freedom of information regimes and from executive dominance of parliaments.

\section{The Concept of 'A Healthy Democracy'}

Just as we need a theory of a good society in order to measure social wellbeing, we need a theory of a healthy democracy to measure democratic progress. As with social progress, the issues that matter to ordinary citizens in democracy can be very different from those which politicians or bureaucrats think important. 
In early work, democratic indicators tended to be limited to the kind of structural issues beloved of political scientists and journalists (such as voting, Parliament and free speech). But over time, as with measures of progress generally, a more comprehensive notion of democratic progress evolved, which included not just the existence of democratic institutions, but a range of non-institutional factors required for a truly healthy democracy (Munck 2009). The Australian Bureau of Statistics was one of the first central statistical agencies to have included 'Democracy, human rights and governance' as a key dimension of progress in its internationally respected report Measures of Australian's Progress.

A more balanced set of indicators of a healthy democracy would measure, not just elections, laws and governments, but also active and knowledgeable citizens, devolution of power, equality of wealth and democratic innovation, as proposed by a framework of democratic health by the Stockholm-based International Institute for Democracy and Electoral Assistance (IDEA), applied now as a benchmark measure in over a dozen countries.

\section{Democracy is a Driver of Progress and Wellbeing in Other Areas}

The quality and effectiveness of democracy and human rights in a society is one of the key drivers of progress and wellbeing. Societies stronger in democracy and human rights achieve better wellbeing for their citizens in practice; one can say that human rights and democracy are good for human wellbeing. This intuitive conclusion is difficult to prove conclusively but there is increasing circumstantial evidence for it.

At an individual level, there has been a growing body of evidence from the World Health Organisation and much social health research that links democracy, participation and social justice with stronger health and wellbeing outcomes (Eckersley 2004; Wilkinson \& Pickett 2009). More recent, and arguably most important, is the report of the World Heath Organisation on socio-economic determinants of health entitled Closing the gap in a generation. This report contains some unequivocal conclusions: "Social justice is a matter of life and death ... Inequities are killing people on a grand scale" (WHO 2008: i).

At the local community level, the links between wellbeing and various forms of participation have been clearly established. In Britain, for example, the Young Foundation (2008), working with renowned happiness researcher Richard Layard, developed six hypotheses showing the link between neighbourhood working and community empowerment, and wellbeing. There is also evidence from international comparisons, demonstrated by a compilation of wellbeing measures for fourteen OECD countries where nations were ranked on their performance on 100 (unweighted) measures of wellbeing across over a dozen dimensions, mostly related to individual wellbeing. A country's 'Overall wellbeing' ranking was then compared to its ranking in a number of other 
fields such as national wealth, environment, public spending, democracy, peace and human rights. Rankings in these fields were also primarily based on compound indexes of multiple measures in each field.

Table 3 shows the results, with the figure in the bottom row designating the correlation between overall wellbeing ranking and ranking in the particular field (a higher number indicates higher correlation).

Table 3: National wellbeing compared to other progress dimensions: Selected OECD countries, ranked by performance, c. 2000-2007

\begin{tabular}{l|ccccccc}
\hline $\begin{array}{c}\text { Country ranked in } \\
\text { order of overall } \\
\text { wellbeing }\end{array}$ & $\begin{array}{c}\text { National } \\
\text { wealth }\end{array}$ & Environment & $\begin{array}{c}\text { Government } \\
\text { spending }\end{array}$ & Democracy & $\begin{array}{c}\text { Income } \\
\text { equality }\end{array}$ & Peace & $\begin{array}{c}\text { Human } \\
\text { Rights }\end{array}$ \\
\hline Sweden & 12 & 3 & 1 & 3 & 1 & 4 & 4 \\
\hline Norway & 2 & 7 & 9 & 4 & 2 & 1 & 4 \\
\hline Denmark & 3 & 2 & 2 & 2 & 6 & 2 & 2 \\
\hline Finland & 10 & 10 & 3 & 1 & 3 & 3 & 1 \\
\hline Netherlands & 5 & 8 & 5 & 5 & 5 & 8 & 3 \\
\hline Austria & 6 & 1 & 6 & 12 & 8 & 5 & 9 \\
\hline Germany & 9 & 6 & 11 & 9 & 7 & 9 & 6 \\
\hline Canada & 4 & 12 & 10 & 7 & 10 & 6 & 8 \\
\hline Belgium & 8 & 11 & 4 & 10 & 4 & 7 & 7 \\
\hline France & 14 & 5 & 8 & 13 & 9 & 12 & 10 \\
\hline UK & 13 & 3 & 12 & 8 & 12 & 13 & 11 \\
\hline Australia & 7 & 14 & 13 & 6 & 11 & 10 & 13 \\
\hline Italy & 11 & 8 & 7 & 14 & 12 & 11 & 11 \\
\hline USA & 1 & 13 & 14 & 11 & 14 & 14 & 14 \\
\hline Correlation with & 6 & 7 & 5 & 4 & 3 & $=1$ & $=1$ \\
\hline overall wellbeing* & & & & & & & 7 \\
\hline
\end{tabular}

*Ranking from 1 (highest correlation) to 7 based on number of instances in which a country's ranking in this area is within 3 places of its ranking in overall wellbeing

The results are not conclusive, but there appears to be a fairly strong link, especially between countries in the top and bottom thirds, between a country's overall wellbeing outcomes, and its performance in three key dimensions: human rights, peace and democracy. On these figures, levels of government spending, generalised trust and income equality would be a better guide to overall wellbeing than national wealth or environmental performance.

\section{Social Progress Indicators Mean Better Governance}

Social progress indicators and frameworks can also be an important tool for better and more accountable governance. A well-developed progress and wellbeing framework can be used: to report conditions in the community; to measure progress and performance against community goals; for planning and priority setting; to enhance democracy and accountability; and to build communities and social cohesion.

Engaging citizens in progress measurement strengthens their democratic capacity. If progress measurement is indeed a global movement, then undoubtedly one of the key drivers of this movement has been the growth 
of local community indicator projects all over the world. The OECD has identified projects in the European Union, Latin America, Italy and France (www.oecd.org/progress); in the US and Canada, hundreds of different community indicator projects have developed over the last fifteen years, and many in Australia, particularly at a local government level. There is plentiful evidence that local governments are increasingly interested in the uptake of social and community indicators (Rawsthorne \& Vinson 2007; Cairns City Council 2006; Victorian Community Indicators Project 2005; City of Sydney 2007). Community wellbeing indicators can improve councils' knowledge, responsiveness, effectiveness and accountability; underpin community planning; and help strengthen their local communities in direct and practical ways.

These projects have had many different causes, including the need to redevelop local communities hit by economic restructure, new laws requiring local governments to develop wellbeing plans and progress measures, or simply the desire of local citizens to be more directly involved in planning the kind of communities that want their children to live in. In the process, community-based wellbeing indicators have become a genuinely new form of democratic participation, as the Sustainable Seattle initiative (www. sustainableseattle.org) acknowledged: "the idea of people taking charge of their own measurements of progress is a powerful and far reaching innovation... [which has] brought about a new sense of civic engagement."

Defining, planning and measuring progress and development in their local communities is a real and meaningful task for citizens, but also a necessary one: because as the foundational work of the Canadian Policy Research Network (CPRN) in the development of the Canadian Index of Wellbeing noted (www. cprn.com), to be legitimate, "societal indicators require the explicit involvement of citizens to determine what matters to them. (Only) then (can) experts ... try to devise the measures that citizens need."

\section{Summary of Australian Work: National Overview}

The development of progress and wellbeing indicators is very much alive and well in Australia, at all levels of government and in the community, triggered initially by the ABS, which had been one of the key players in the OECD's 1970s project on social indicators. After the OECD project was wound down in the early 1980s, however, the idea of a national wellbeing measurement program was not pursued again in Australia until nearly twenty years later.

In the early 1990s, a combination of academic and community interest, and new energy from the ABS, led to a series of research studies, projects and conferences, and in 1995, the establishment of a parliamentary inquiry to examine the feasibility of a system of national indicators for citizenship and wellbeing. In 2000, the ABS established a major new initiative entitled Measuring Australia's Progress, and in doing so, it became one of the first national statistics agencies to produce an integrated framework of key progress measures which looked beyond GDP, to social, environmental, cultural and democratic, as well as economic, progress. 
In the same period, local governments and community organisations across Australia had begun to take an increasing interest in developing community based progress measures for many of the same kinds of reasons that applied in other countries: to counteract economic decline, to improve planning, to re-engage alienated citizens, or because of new legislative reporting requirements. At the state government level, having improved progress measures had become increasingly important both for long-term state planning, and as the basis for neighbourhood renewal programs in areas of major disadvantage.

Today, a wide range of local government and neighbourhood organisations actively operate community based progress indicator systems and projects. The state of Victoria has a state-wide system and website to support its 79 local governments (Victorian Communities Indicators Project 2005), with its mission "to provide reliable community indicators to all local governments and communities and to help them develop new models of community engagement and stronger capacity to develop and community use indicators."

At the heart of the CIV's common model is its community wellbeing measurement framework, based on the inputs from all local governments. The framework is built around 5 wellbeing domains and 80 key indicators and a similar system is being planned for the state of Queensland. Tasmania Together is a community-based long term plan for the State. It includes 12 goals and 143 benchmarks that reflect the concerns people expressed during two of the biggest community consultation processes ever undertaken in Tasmania (in 2000 and 2005) (see www.tasmaniatogether.tas.gov.au).

These state projects owe a great deal to generous help from Canada's world-leading 'Community Accounts' indicator system developed by the provincial government of Newfoundland and Labrador (see www. communityaccounts.ca), and US projects such as 'Oregon Benchmarks' (see www.oregon.gov/DAS/OPB/os.shtml ).

One other interesting application of community indicators in Australia has been in the redevelopment of disadvantaged neighbourhoods. A critical requirement of good neighbourhood renewal policy is to involve residents themselves in all stages of redevelopment from planning and priority setting to implementation and monitoring. This was done in both Victoria (Neighbourhood Renewal) and Queensland (Community Renewal) by identifying resident leaders and training them to help design and administer community surveys and focus groups, in which the residents identify their needs and desired outcomes in concrete terms which can be then readily transformed into indicators. Interestingly, community surveys of this kind were sometimes criticised by academics as biased, but in fact, they provided better information and a stronger sense of ownership, than if undertaken as a detached academic exercise.

\footnotetext{
${ }^{1}$ See the paper by Cox and colleagues in this issue.
} 


\section{National Development Index proposal}

Perhaps the most exciting and challenging community indicators project in Australia today is the proposal for an Australian National Development Index (NDI). This ambitious project is seeking to draw together the community indicators movement across Australia into a cooperative venture. Its aim will be to build an ongoing national progress and wellbeing framework that measures true progress against goals and benchmarks developed jointly by citizens and experts.

The project took a giant step to realisation in 2008 with the election of a new federal Labor government, and the convening of the April 2008 national 'Ideas Summit' where the idea of a NDI emerged as a strong priority.

The NDI is at an early stage in its life, but it will be designed to draw from the best models available in the world. These include: the Canadian Index of Wellbeing (CIW) and Bhutan's Gross National Happiness (GNH) project (perhaps the most advanced national models in the world today) and the pre-eminent international project, the OECD's Measuring the Progress of Societies. Furthermore, the NDI will be looking closely at the work of the luminary Stiglitz Commission, initiated by the French President Sarkozy in 2008, with a broad mandate to identify the limits of GDP as an indicator of economic performance and social progress, to consider additional information required for the production of more relevant indicators, to discuss how to present this information in an appropriate way, and to assess the feasibility of alternative measurement tools' (www.stiglitz-sen-fitoussi.fr/en/index.htm).

It will be critical to continue reviewing the factors that contribute to the success and failure of community indicator projects, identifying the types of desired outcomes that communities are trying to achieve, as Dluhy and Schwartz (2006) have done in the United States. Certainly, the NDI is fortunate to have as a partner a national statistical agency (the ABS) which has already developed an internationally regarded statistical framework for measuring progress. The NDI will extend this work in a way that enables wider community participation, and the incorporation of actual policy goals as progress benchmarks, a process in which central statistics agencies cannot be expected to take the lead.

In doing so, the NDI will be cognisant of new research into the utility of indicator systems from a community-based perspective, beginning from the characterization of indicators and their uses provided by Herzi \& Dovers (2006) and Hagerty et al. (2001). They both create typologies, not of the population groups using indicators but of the types of use to which they are put: instrumental, conceptual, tactical, symbolic, or political. They offer a conceptualisation of indicator systems as a bridge between knowledge and policy and posit that the length of this bridge, or the distance of different users from decision-making authority, determines the type of function the indicators fulfil as well as the costs of invoking them. Only more recently developed is research into the specific social and political factors that determine whether and 
how indicators get developed and used, despite widespread recognition that these factors present the biggest barriers to effective application of indicators in any context (Rydin 2007; Michalos 2007; Reed et al. 2006; Eckerberg and Mineur 2003; Gahin et al. 2003; Besleme et al. 1998). Understanding the contexts of community indicators will demand highly engaged scholarship, as Sawicki's (2002) comprehensive overview of community indicator systems globally concluded, recommending that each community indicator system project should have a qualified social science scholar engaged in the development of its unique approach.

The challenges for the Australian NDI will be substantial: to enable broad democratic and community engagement in its values and specific measures; to develop a satisfactory technical model of progress and wellbeing and an attractive and accessible public platform on which to display it; to produce a common set of indicators which can be used at all three levels of government (local, state and federal) to enable shared planning and goals; and finally, through concrete indicators and benchmarks, to build a credible long term vision for Australia's development. By doing this, the NDI has the potential to put citizens on an equal footing with experts and politicians, which, in issues of this kind they should be. As Albert Einstein reminded us in the dedication to Waring's (1988) seminal Counting for Nothing:

We should be on our guard not to overestimate science and scientific methods when it is a question of human problems: and we should not assume that experts are the only ones who have a right to express themselves on questions affecting the organisation of society.

\section{Conclusion}

Certainly the scale at which community driven progress and sustainability indicators have grown in the past decade suggests that what began as a series of diverse experiments is already a global movement. And there is now some optimism that this global movement may bring a paradigm shift in public policy, which threatens to replace two long dominant assumptions: the primacy of continuous economic growth as the key driver of wellbeing; and the historically powerful but deterministic notion of the 'inevitability of progress'.

In their place, this new paradigm offers a more holistic, integrated and nuanced model that recognises the interdependence of economic, social, cultural, environmental and democratic dimensions for equitable and sustainable wellbeing: that is, genuine progress. The most important outcome of the OECD's project on measuring progress may ultimately be the fact that it has launched a global democratic debate about the meaning of progress. And interestingly, this debate signals a possible convergence between European and Asian public policy models, as from different starting points (Positivism on one hand, Buddhism on the other) both seek to move 'Beyond GDP' and towards 'Gross National Happiness'. 
This conclusion was strikingly evident in November 2007 for anyone attending both the European Union conference 'Beyond GDP' in the European Parliament in Brussels, and immediately after, the Third Gross National Happiness conference in Chang Mai. The language and values were different, and the settings and participants could not have been more unalike, but the message from both of these very different conferences was exactly the same: 'It is time to end the mismeasurement of progress by economic growth alone, and to move to a new and more legitimate paradigm that is people centred, equitably distributed and environmentally and socially sustainable'.

\section{References}

ABS (2006) Measures of Australia's Progress, available at <http://www.abs.gov. au/AUSSTATS/ >, accessed 10 February 2010.

Adams, D. \& Hess, M. (2001) 'Community in Public Policy: Fad or Foundation?', Australian Journal of Public Administration, 60 (2), 13-24.

Bauer, R.A. (1967) Social Indicators, Cambridge, MA: M.I.T. Press.

Besleme, K. Erquiaga, E. \& Swain, D. (1998) 'Community Indicator Projects: Practical Tools for Addressing the Quality of Life', Proceedings of the First International Conference on Quality of Life in Cities, 4-6 March, National University of Singapore, Singapore.

Cairns City Council (2006) Liveability Report 2005/06, Cairns: Author.

Callahan, K. (2007) 'People, Politics, Participation and Place', Public Administration Review, 67 (5), 950-954.

Chapman, J. (2004) System Failure: Why Governments must Learn to Think Differently, London: Demos.

City of Sydney (2007) Baseline Indicators Working Paper: Sustainable Sydney 2030, Sydney: SGS Economics \& Planning.

Cobb, C. \& Rixford, C. (1998) Lessons Learned from the History of Social Indicators, San Francisco: Redefining Progress.

Dalton, R. (2004) Democratic Challenges, Democratic Choices: The Erosion of Political Support in Advanced Industrial Democracies, London: OUP.

Dluhy, M. \& Swartz, N. (2006) 'Connecting Knowledge and Policy: The Promise of Community Indicators in the United States', Social Indicators Research, 79(1), 1-23.

Eckerberg, K. \& Mineur, E. (2003) 'The use of local sustainability indicators: Case studies in two Swedish municipalities', Local Environment, 8(6), 591-614.

Eckersley, R. (2004) Well and Good: How We Feel and Why it Matters, Melbourne: Text Publishing.

Estes, R. (1984) The Social Progress of Nations, New York: Praeger Publishers.

Gahin, R., \& Paterson, C. (2001) 'Community Indicators: Past, Present and Future', National Civic Review, 90(4), 347-361. 
Gahin, R., Veleva, V., \& Hart, M. (2003) 'Do indicators help create sustainable communities?', Local Environment, 8(6), 661-666.

Henderson, H. (1991) Paradigms in Progress: Life Beyond Economics, San Francisco: Berrett-Koehler Publishers.

Hagerty, M., Cummins, R., Ferriss, K., Michalos, A., Perterson, M., Sharpe, A., Sirgy, J. \& Vogel, J. (2001) 'Quality of life indexes for national policy: review and agenda for research', Social Indicators Research, 55, 1-96.

Herzi, A.A. \& Dovers, S.R. (2006) 'Sustainability indicators, policy and governance: Issues for ecological economics', Ecological Economics, 60, 86-99.

Inkeles, A. (Ed) (1991) On Measuring Democracy: Its Consequences and Concomitants, New York: Transaction.

Land, K. (1974) Social Indicator Models: An Overview, New York: Columbia University.

Michalos, A. (2007) 'Connecting communities with community indicators', Second OECD World Forum on Statistics, Knowledge and Policy, Istanbul, 27-30 June 2007.

Munck, G. (2009) Measuring Democracy: A Bridge Between Scholarship And Politics, New York: John Hopkins University Press.

Putnam, R. (2000) Bowling Alone: The Collapse and Revival of American Community, New York: Simon \& Schuster.

Rawsthorne, M. \& Vinson, T. (2007) 'The Most Liveable Place in Australia: The Role of Social Indicators in Realising the Vision', New Community Quarterly, 5 (4), 3-10.

Reed, M.S.; Fraser, E.D.G. \& Dougill, A.J. (2006) 'An adaptive learning process for developing and applying sustainability indicators with local communities', Ecological Economics, 59(4), 406-418.

Rydin, Y. (2007) 'Indicators as a governmental technology? The lessons of community-based sustainability indicator projects', Environment and Planning, Development, Society \& Space, 25, 610-624.

Salvaris, M. (2002) Community Indicators and Local Democracy, Melbourne: Swinburne Institute for Social Research.

Salvaris, M. \& Wiseman, J. (2004) Mapping Community Wellbeing: Using community wellbeing indicators to choose goals and measure progress, Carlton, Victoria: Victorian Health Promotion Foundation.

Sawer, M.; Abjorensen, N. \& Larkin, P. (2009) Australia: The State of Democracy, Melbourne: Federation Press.

Sawicki, D. (2002) 'Improving Community Indicator Systems: Injecting More Social Science into the Folk Movement', Planning Theory \& Practice, 3(1), 13-32.

Smyth, P., Reddel, T. \& Jones, A. (Eds) (2005) Community and Local Governance in Australia, Sydney: UNSW Press. 
United Nations Development Programme (UNDP) (1996) Human Development Report 1996, Oxford: Oxford University Press for United Nations Development Programme.

Victorian Community Indicators Project (2005) Measuring Wellbeing, Engaging Communities, Discussion Paper, available at $<$ http://www. communityindicators.net.au/webpage/items/09318-upload-00001.pdf>.

Victorian Government (2000) Growing Victoria Together, Melbourne: Author.

Vinson, T. \& Homel, R. (1976) Indicators of Community Well-being, Canberra: Australian Government Publishing Service.

Waring, M. (1988) Counting for Nothing, Wellington: Bridget Williams.

WHO (2008) Closing the Gap in a Generation: Health Equity Through Action on the Social Determinants of Health, Final Report of the Commission on Social Determinants of Health, Geneva: World Health Organization.

Wiseman, J.; McLeod, J. \& Zubrick, S. (2007) 'Promoting Mental Health and Well-being: Integrating Individual, Organisational and Community-Level Indicators', Health Promotion Journal of Australia, 18 (3), 198-207.

Wilkinson, R. \& Pickett, K. (2009) The Spirit Level: Why More Equal Societies Almost Always Do Better, London: Allen Lane.

Woolcock, G. \& Manderson, L. (Eds) (2009) Social Capital \& Social Justice: Critical Australian Perspectives, Darwin, NT: CDU Press.

Young Foundation (2008) 'Neighbourliness + Engagement = Wellbeing', available at <http://www.youngfoundation.org.uk/publications/reports>.

\section{Websites}

Canadian Index of Wellbeing <http://www.cprn.com>

Community Accounts' Indicator System <http://www.communityaccounts.ca>

Oregon Benchmarks <http://www.oregon.gov/DAS/OPB/os.shtml>

Stiglitz Commission <http:// www.stiglitz-sen-fitoussi.fr/en/index.htm>

Tasmania Together <http://www.tasmaniatogether.tas.gov.au> 